\title{
Hydroxyapatite Synthesis and Covering of Titanium Surfaces by Dip-Coating Method
}

\section{Luiz Alexandre Chisini ${ }^{1,2^{\star}}$}

https://orcid.org/0000-0002-3695-0361

Gian Francesco dos Reis Paganotto ${ }^{3}$

https://orcid.org/0000-0001-9917-0330

Rodrigo Guergolette ${ }^{3}$

https://orcid.org/0000-0001-7032-9766

Marcus Cristian Muniz Conde ${ }^{2}$

https://orcid.org/0000-0003-2662-3305

\author{
Jose Carlos Bernedo Alcázar ${ }^{1}$ \\ https://orcid.org/0000-0002-9500-5327 \\ Rodrigo Varella de Carvalho 4 \\ https://orcid.org/0000-0002-2644-5820
}

\author{
Evandro Piva 1 \\ https://orcid.org/0000-0002-5970-5158 \\ Neftali Lenin Villarreal Carreño ${ }^{3}$ \\ https://orcid.org/0000-0002-5780-817X
}

\begin{abstract}
${ }^{1}$ Federal University of Pelotas, Graduate Program in Dentistry, School of Dentistry, Pelotas, Rio Grande do Sul, Brazil; ${ }^{2}$ University of Vale do Taquari, Graduate Program in Dentistry, School of Dentistry, Lajeado, Rio Grande do Sul, Brazil; ${ }^{3}$ Federal University of Pelotas, Graduate Program in Science and Material Engineering, Pelotas, Rio Grande do Sul, Brazil; ${ }^{4}$ Meridional Faculty (IMED), Department of Restorative Dentistry, School of Dentistry, Passo Fundo, Rio Grande do Sul, Brazil.
\end{abstract}

Editor-in-Chief: Paulo Vitor Farago

Associate Editor: Fábio André dos Santos

Received: 2020.06.03; Accepted: 2021.07.07.

*Correspondence: alexandrechisini@gmail.com; Tel.: +55-53-981121141 (L.A.C.).

\section{HIGHLIGHTS}

- Coating method suggest an easy and viable alternative to produce HAp films.

- Dip-coating method was effective to produce a HAp film on titanium cylinders.

- Cell viability over the HAp-modified cylinders was not altered.

- Dip-coating method present adequate control of deposition of thin films of hydroxyapatite.

Abstract: This study developed and characterized a method for controlled deposition of thin films of hydroxyapatite on titanium surfaces. Thirty-three titanium cylinders were randomly divided: negative control/polished $(A)$, acid etched $(B)$ and coated by hydroxyapatite $(C)$. Acid etch was performed in an aqueous solution of nitric acid. The cylinders were subjected to coating by a thin film of hydroxyapatite with dip-coating method. These cylinders were submitted to a pre-heat treatment $450^{\circ} \mathrm{C} / 10$ minutes and $800^{\circ} \mathrm{C} / 2$ hours. Scanning electron microscopy analysis demonstrated a homogeneous and smooth surface (A), an irregular and porous surface (B) and a crystalline deposition (C). The X-ray energy dispersive analysis showed characteristic elements of hydroxyapatite $(\mathrm{C})$. Analysis by X-ray diffraction showed the presence of characteristic peaks of hydroxyapatite, corresponding to the structural composition of hydroxyapatite. Cell viability (MTT-assay in NIH-3T3-Cells) test demonstrated no differences between the groups. Titanium surfaces coated with a hydroxyapatite film by the dip-coating method suggest adequate control of deposition of thin films of hydroxyapatite and similar cell viability using mouse fibroblasts. 
Keywords: Dental titanium; dip-coating; hydroxyapatite.

\section{INTRODUCTION}

The edentulism presents elevate prevalence [1, 2] mainly due to caries [3] and periodontal disease [4] and its treatment with dental implants is today one of the most predictable and successful treatments. Dental implants are a well acceptable treatment to recover partial and fully edentulous patients $[5,6]$, showing high clinical survival, ranging from $96.4 \%$ [7] to $88 \%$ [8] in periods between 10 to 23 years [8-12]. Titanium is a biocompatible material commonly used in implants due to its mechanical properties and chemical stability. Such characteristics allow satisfactory tissue reaction, bone matrix formation and low immune response [7, 11]. Despite the high clinical success rates, implants failure were reported especially in older patients, patients with poor quantity and quality of remaining bone or poor wound healing due to systemic problems, such as osteoporosis or diabetes [13,14]. Therefore, modifications on the macro and micro structural design of the dental implants have been investigated $[15,16]$ to both, reduce the time required for general osseointegration and improve the clinical success rate in patients with systemic problems. In this sense, different technologies for surface treatments have been proposed [17]. Subtractive and additive surface treatments as sand/grit blasting, coating, acid-etching, anodic oxidation, electrochemical, thermal, laser treatments, or a combination of techniques are widely used today [17, 18]. The main objective of this techniques is to increase the roughness of the implant, and consequently, the surface energy, which can positively induce the cellular activities, enhancing peri-implant bone wound healing [19].

Chemical coatings have been used in order to produce surfaces with different topographies and to enhance the potential of osseointegration [17]. The deposition of bioactive ceramics such as hydroxyapatite (HAp) is a widely used technique to modify the implant surfaces [17]. HAp is a component of mineralized tissues such as bone and tooth. The application of HAp depends on its bioactive properties and the formation of a biological layer of apatite [20,21]. HAp coating deposition promotes the enhancement of peri-implant bone formation [22] especially in areas where the ceramic is present [20]. Most HAp coatings are obtained by a plasma spray method [23]. However, some drawbacks related to the plasma spray method were reported, such as low mechanical strength, poor bonding with the substrate, high thickness (>30um) and high porosity of the coatings [21, 23]. These problems are a consequence of the high temperature needed to the deposition and the thick of the coating layer [23]. In addition, titanium surfaces coated with HAp tended to rapid solubilization after some years, and that might lead to premature failure of the implants [24].

Therefore, there is also a gap in the literature concerning methods that can control the thickness, stability, and porosity of the coatings [15]. The sol-gel technique is an environmental friendliness and makes it an attractive approach for synthesizing highly bioactive and biocompatible materials. Thus, the intrinsic bioactivity of the sol-gel materials together with the likelihood to be coupled with a wide variety of coating techniques, such as the dip-coating, mainly because dip-coating method promotes better absorption of calcium phosphate and produce thinner coatings [25]. Yet, few studies used the dip-coating technique to deposit HAp on the surface of medical titanium [25, 26]. Thus, the purpose of this study was to synthesize, characterize and evaluate the cell viability of titanium surfaces recovered by films of HAp using the dip-coating technique.

\section{MATERIALS AND METHODS}

Thirty-three commercially titanium cylinders (diameter $4 \mathrm{~mm}$, thickness $1.5 \mathrm{~mm}$ ) produced and supplied by Ferreira Dental Industry, Ltda. (Grade-5 titanium alloy [Ti6Al4V],

Paraná, Brazil) were selected to this study. They were randomly divided into three groups $(n=11)$ according to the surface treatment: (A) polished (negative control), (B) acid etched (nitric acid) and (C) HApcoated by dip-coating method. The titanium cylinders preparation process followed three stages as follow.

\section{Surface treatment and preparation of sol-gel solution}

Firstly, all titanium cylinders were ground and polished with silicon carbide abrasive paper from grit 60 to 1200 respectively, under continuous water cooling for 5 minutes, to standardize the roughness of the surface.

After, all surfaces were cleaned with distillate water in an ultrasonic machine for 15 minutes. Thus, eleven cylinders were randomly selected to form group A (only polished). Thereafter, the twenty-two remaining cylinders were subjected to nitric acid etch $(2.73 \mathrm{~mol} / \mathrm{L})$. The titanium surfaces were covered with $2 \mathrm{~mL}$ of the nitric acid solution during one minute. Subsequently, the acid was neutralized and rinsed with distillate water 
for 5 minutes to remove completely the acid, and then, eleven more cylinders were selected to form the group B.

HAp preparation followed the technique described by Varma and Babu [27]. An anhydrous citric acid solution was prepared previously to the HAp synthesis. The solution results from a mixture of $10.5 \mathrm{~g}$ of citric acid with $20 \mathrm{ml}$ of distilled water. The solution was mixed on a magnetic shaker for 10 minutes at $80^{\circ} \mathrm{C}$ until the solution became homogeneous. After, the citric acid solution $\left[\mathrm{C}_{6} \mathrm{H}_{8} \mathrm{O}_{7}\right]$ received $5.92 \mathrm{~g}$ of calcium nitrate $\left[\mathrm{Ca}\left(\mathrm{NO}_{3}\right)_{2} 4 \mathrm{H}_{2} \mathrm{O}\right]$ and $1.73 \mathrm{~g}$ of dibasic ammonium phosphate $\left[\left(\mathrm{NH}_{4}\right)_{2} \mathrm{HPO}_{4}\right]$. This solution was mixed for 15 minutes at $80^{\circ} \mathrm{C}$.

The HAp deposition procedure was performed in an equipment for thin film coatings by immersion and emersion process, known as dip-coating method. In this study, was used a stainless-steel metallic device to fix the cylinders by their sides, to avoid contact of the machine shaft and to ensure the full immersion of the cylinders surfaces in the solution. The immersion and emersion speed were $10 \mathrm{~mm} / \mathrm{s}$, the time of immersion was 10 seconds and the time of emersion was 10 minutes. Then, the cylinders were kept at rest for one hour at room temperature for one hour.

After, the cylinders were subjected to a thermal pre-treatment at $450^{\circ} \mathrm{C}$ for 10 minutes. This pre-treatment aimed to accelerate the transformation of the solution in gel (sol-gel), forming directly the oxide. Then, a muffle type oven was used, in which the cylinders were submitted to $800^{\circ} \mathrm{C}$ treatment for 2 hours.

\section{Surface characterization of the Ti cylinders}

Surface morphology of the Ti cylinders $(n=3)$ was performed by scanning electron microscopy (Superscan SSX-550 SEM, Shimadzu Corporation) in triplicate. The metal samples were analysed directly since as they present electrical conductivity, thus the interaction between the electron beam and the sample surface is responsible for the analysis. The HAp coated samples were prepared by the sputtering technique with gold to obtain conductivity of the electron beam needed on the surface. Analyses were performed in different distances (40X and 1000X).

Chemical analysis was performed by Energy Dispersive X-Ray Fluorescence Spectrometer using the EDX 720 (Shimadzu Corporation). This analysis identifies and quantifies the chemical components through different radiation emitted by the atoms comprising the material of interest in the analysis. The cylinders were analysed before and after the coating process.

X-ray diffraction analysis was carried out in the XRD-6000 equipment (Shimadzu Corporation). The powder used in the sol-gel process submitted to thermal treatment was obtained separately to solution prepared in the coating method and at a temperature equal than the one used in the coating and was analysed by X-ray diffraction to assess whether calcium phosphate was formed as a coating. The analysis of the crystalline powder of hydroxyapatite was performed using a radiation source of $\mathrm{Cu}-\mathrm{k}$ with a wavelength of $0.1546 \mathrm{~nm}$, powered by $30 \mathrm{KV}$ and $30 \mathrm{~mA}$, at $20^{\circ}$ to $70^{\circ}$ angles and a scan rate of $1^{\circ}$ per minute.

\section{Cell Viability test}

The titanium cylinders ( $n=8$ per group) were sterilized by UV radiation during $1 \mathrm{~h}$ on each side in a laminar flow cabinet. The specimens were stored at $37^{\circ} \mathrm{C}$ for $24 \mathrm{~h}$ in a sterile container prior to testing. For cell proliferation test $[28,29]$, the titanium cylinders $(h=1.5 \mathrm{~mm}, \varnothing=4 \mathrm{~mm})$ were placed at the bottom of 48well plates previously to cell seeding. 3T3/NIH mouse fibroblasts $\left(5 \times 10^{4}\right)$ were cultured over the cylinders surface in Dulbecco's Modified Eagle's Medium (DMEM) supplemented with 10\% fetal bovine serum and $1 \%$ antibiotics $(10,000 \mathrm{IU} / \mathrm{mL}$ of penicillin $\mathrm{G}$ and $10,000 \mathrm{mg} / \mathrm{mL}$ of streptomycin). All reagents were supplied by Gibco Laboratories Inc., Grand Island, NY, USA. The cells were maintained in an incubator $\left(37^{\circ} \mathrm{C}, 5 \%\right.$ of $\mathrm{CO}_{2}$ ) for $24 \mathrm{~h}$. The titanium cylinders were then transferred to a new 48-well and a solution of $5 \mathrm{mg} / \mathrm{ml}$ of MTT (3-(4,5-dimethylthiazol-2-yl)-2,5-diphenyltetrazolium bromide) was added and maintained for $4 \mathrm{~h}\left(37^{\circ} \mathrm{C}, 5 \%\right.$ of $\mathrm{CO}_{2}$ ) in contact with the cells to allow the reduction of tetrazolium salts by viable cells. Absorbance readings were measured using a universal ELISA reader (ELX 800; BIO-TEK Instruments, Winooski, VT, USA), with a $540 \mathrm{~nm}$ wavelength filter, where absorbance values were considered as an indicator of cell viability. Cell viability test was performed in triplicate. Statistical analysis was performed by one-way analysis of variance followed by a Bonferroni's post hoc test. The level of significance was set at $p<0.05$. Statistical analyses were carried out with SigmaStat ${ }^{\circledR}$ software package (Version 3.5 for Windows ${ }^{\circledR}$; Systat Software Corporation, San Jose, CA, USA). 


\section{RESULTS}

\section{Surface morphology}

The surface pattern of the titanium cylinders before and after the different surface treatments can be observed in Figure 1. SEM images showed that different surface treatments produced different surface patterns. The titanium surface before any treatment presented grooves and marks formed by the machine tool used (Figure 1A and 1B). Samples after polishing showed a surface with smooth aspect (Figure 1C and 1D), while the acid treatment produced an irregular surface (Figure 1E and 1F). Figure 2 shows the surface pattern obtained after the HAp coating in different magnitudes. It can be observed that HAp coated samples have an irregular and crystalline aspect with different size particles on it (Figure 2A, 2B and 2C).
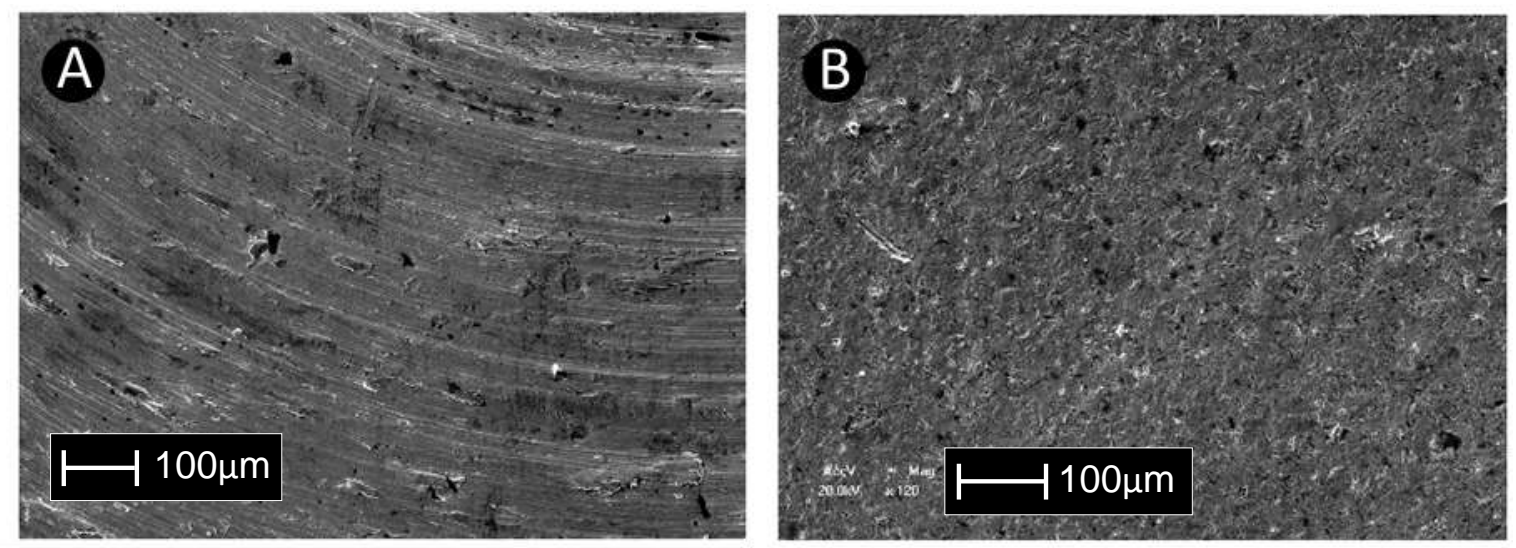

Figure 1. Surface patterns in negative control/polished group (A), and acid etched group (B).
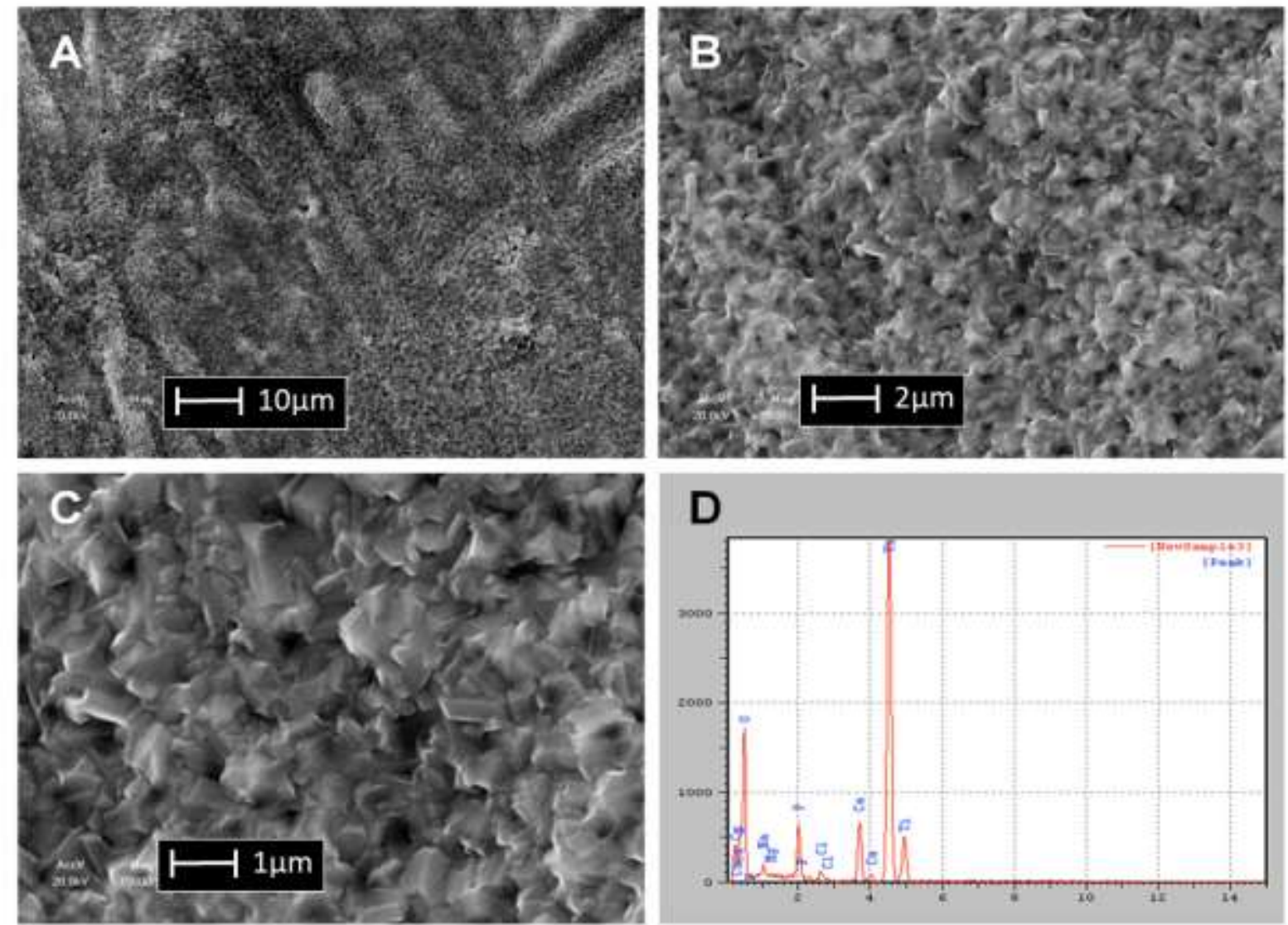

Figure 2. The surface pattern obtained after $\underline{\mathrm{HAp}}$ coating in different magnifications $(2 \mathrm{~A}-10 \mu \mathrm{m} ; 2 \mathrm{~B}-2 \mu \mathrm{m}$; and $2 \mathrm{C}-1 \mu \mathrm{m})$. The chemical analysis by $\mathrm{X}$-ray fluorescence is shown by the spectrum obtained from the surface of the HAp coated cylinders (2D). 


\section{Chemical analysis by Energy Dispersive X-Ray Fluorescence Spectrometer}

Chemical analyses are shown in Table 1. The X-ray fluorescence showed the inorganic composition of the HAp on the titanium cylinders. The percentages of calcium and phosphorus suggest the presence of HAp. Titanium cylinders without treatments showed titanium. In Figure 2D can also be observed that the spectrum obtained from the surface of the HAp coated cylinders.

Table 1. Quantitative results of chemical analysis by X-ray fluorescence.

\section{Control Surface}

Acid-etched

Coated Surface

\begin{tabular}{|c|c|c|c|c|c|}
\hline Element & Quantity (\%) & Element & Quantity (\%) & Element & Quantity (\%) \\
\hline$\overline{\mathrm{Ti}}$ & 99.8 & $\mathrm{Ti}$ & 99.8 & $\mathrm{Ti}$ & 98.6 \\
\hline $\mathrm{Eu}$ & 0.2 & $\mathrm{Eu}$ & 0.2 & $P$ & 0.7 \\
\hline - & - & - & - & $\mathrm{Ca}$ & 0.7 \\
\hline
\end{tabular}

\section{Analysis by X-Ray Diffraction}

The analysis showed characteristic peaks of HAp, according to the validated record of Powder Diffraction File (PDF) from International Centre for Diffraction Data (ICDD): 09-0432, that corresponds to the structural composition of HAp (Figure 3).

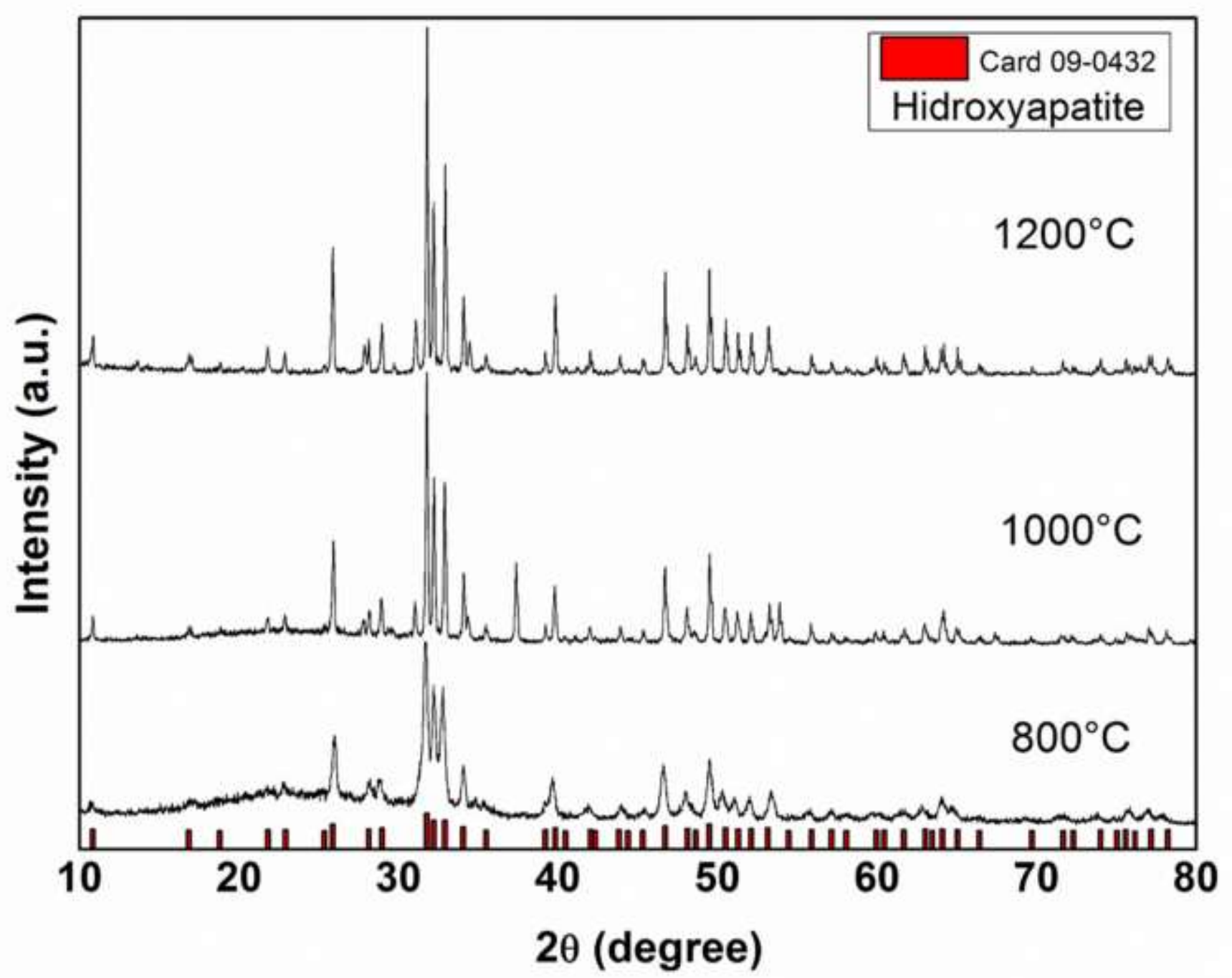

Figure 3. The analysis by X-ray diffraction of the crystalline powder of HAp showed the presence of characteristic peaks of HAp. 


\section{Cell Viability Assay}

Table 2 shows the cell viability test results for the different titanium surface treatments evaluated. All surfaces showed the same cell viability after 24 hours of contact with the $3 \mathrm{~T} 3 / \mathrm{NIH}$ mouse fibroblasts (Table 2).

Table 2. Cell viability (mean \pm S.D.) after $24 \mathrm{~h}$ of contact between mouse fibroblasts $(3 T 3 / \mathrm{NIH}$ ) and different titanium surface treatments.

Control Surface Acid-etched Coated Surface

$0.61(0.02)^{\mathrm{a}} \quad 0.4(0.1)^{\mathrm{a}} \quad 0.6(0.2)^{\mathrm{a}}$

Different lowercase letters denotes significant difference $(\mathrm{P}<0.05) .{ }^{*}$ absorbance was performed at 540nm

\section{DISCUSSION}

The present study showed that the dip-coating method was effective to produce a HAp film on titanium cylinders. The pre-thermal treatment of titanium surfaces reduced the time required to transform the solution of HAp into a gel, allowing the HAp deposition. Cell viability over the HAp-modified cylinders was comparable between the groups and the roughness of the surfaces was preserved. Roughness is an important characteristic of implant topography, since it is one of the most important modulators of the cell adhesion and osteoblast differentiation [30]. The higher roughness significantly increased the mRNA levels of biomolecules (such as BMP2 and BMP4) as well as the level of BMP4 secreted by osteoblasts on titanium surfaces [31]; roughness seems improve osteoinduction due to the increasing the mechanical retention (interdigitation) and provide good stress distribution [18,32].

The surface treatment with acid etching was carried out in order to improve the interface union between the titanium substrate and the HAp film deposited. The dip-coating method (DCM) is based on a wellcontrolled immersion process [33]. The speed and time of immersion are determinant factors on film thickness [26]. Generally, DCM allows for the attainment of very thin films, one desired property to maintain the original surface roughness. A review comparing deposition of HAp coating with different techniques found that DCM provide a thickness ranging from 0.05 to $15 \mathrm{~mm}$ [34]. Thick or irregular coating layers might modify the surface roughness and consequently produce heterogeneous textures. Irregular films are not desirable since could negatively interfere with cell adherence, differentiation, and consequently, on osseointegration [26, 33, 35, 36].

In the present study, even though the thickness of the HAp film formed on titanium surface was not measured, the low percentages of $\mathrm{Ca}$ and $\mathrm{P}$ in the chemical analysis suggest that the layer of HAp could be thin. Additionally, other studies applying DCM also produced thin layers of Hap [26, 34, 37]. Cross-section SEM micrograph in a similar study found a coating thickness ranging from 1-2 $\mu \mathrm{m}$ to $3-4 \mu \mathrm{m}$ on the inner surface [38]. In this way, sol-gel preparation combined with DCM have been one of the best coating methods for improve adhesion strength [39-41]. The temperature applied during the coating process can interfere in both, the thickness and the structure of the films. This could induce the presence of scratches, or failure areas, decreasing the adhesion between HAp and titanium surface [23, 26].

The thermal pre-treatment was performed to accelerate the sol-gel process and to reduce the temperature, avoiding crack formation on film microstructure. The study of Alkasan et al, indicated that lower sintering temperature is desirable to avoid significant phase changes in the microstructure [26]. The film produced in the present study was obtained below $800^{\circ} \mathrm{C}$, which generated a surface with typical appearance, cohesive and structure of a HAp coating. Yet, it can be observed a melted appearance of HAp, with a dense and continuous structure, without cracks or scratches. Other studies reported similar surface characteristics [25] using the same temperature [26]. Furthermore, the size of the HAp powder, gelation materials and process are determinants on the surface obtained [26].

The chemical composition of HAp solution applied during the experiment possess the main phase of HAp. The presence of HAp can be macroscopically observed depicted as an opaque surface produced by HAp and titanium oxide. Such characteristic has been reported when DCM techniques are applied to obtain HAp-covered surfaces [22, 24, 37]. Cell adhesion over the titanium surfaces is determinant for osteoinduction and, consequently, for osseointegration to occur. Cell adhesion on HAp-modified titanium surfaces was evaluated by MTT assay, which is based on the reduction of tetrazolium salts (MTT) by the mitochondrial dehydrogenase enzyme in viable cells [42]. To avoid a possible bias determined by the cells attached to the 
bottom well, the titanium cylinders were transferred to a new 48-well plate, after cell adhesion, to perform the MTT assay. This allowed the evaluation of cell viability only of those cells attached on the titanium surface. The absorbance results did not produce statistical differences between the groups. Other studies evaluating titanium surfaces coated with HAp by other methods showed similar results, being sustained that the apatite layer formed on the coated surface is able to maintain or improve cell activity [15, 43-46]. Moreover, in an in vivo model evaluation, HAp-based coatings on titanium implants promoted bone remodelling and inflammatory response after eight weeks using the rabbit tibia model [47]. In fact, biological proprieties such as osteogenesis could be improved using this strategy [15], which cell adhesion is an essential and initial process directly involved in cell growth, migration and differentiation.

Titanium surfaces coated with hydroxyapatite could procedure calcium phosphate, a significant composite, able to enhance bonding to bone $[15,48]$. It seem be able to precipitate bone-like HAp and induce osteogenesis of bone precursor cells in a fluid medium $[15,49]$. In the present study, it was found a similar deposition of calcium and phosphate observed in the chemical analysis by X-ray fluorescence analysis; thus, these molecules can provide cellular signals that promote osteoblasts differentiation, facilitating the mineralization process during bone formation.

Therefore, other studies should be conducted to elucidate some aspects of this preliminary study that used an interesting methodology to produce titanium surfaces coated by HAp. Important questions like bond strength between the HAp and titanium surface, to predict if eventual dislocations of the HAp film during implantation could happen, since previous in vivo studies observed such situation; thus, it can be also assessed by a micro scratch test to complement our preliminary findings. Besides, the thickness of HAp deposition could be investigated in further studies through the SEM cross-section evaluation. Further studies should perform a FTIR analysis directly at the titanium coated surfaces to attest the presence of HAp characteristic absorption bands, as well as the surface roughness could also be quantitatively acquired by a profilometer or by AFM. In this way, a better comparison of cell attachment and coating influence could be inferred. Yet, in vitro studies using other cell types could be performed to investigated the potential to produce cell differentiation and osteogenesis by the HAp-coated titanium cylinders, as well as to evaluate the in vivo performance of these modified titanium implants.

Thus, the coating method used in this study suggest an easy and viable alternative to produce HAp films and titanium coated surfaces.

Conflicts of Interest: The authors report no conflicts of interest.

\section{REFERENCES}

1. Chisini LA, Sarmento HR, Collares K, Horta BL, Demarco FF, Correa MB. Determinants of dental prosthetic treatment need: A birth cohort study. Community Dent Oral Epidemiol. 2020.

2. Chisini LA, Sarmento HR, Horta BL, Demarco FF, Correa MB. Normative and subjective need for dental prosthesis: accuracy and agreement in a population based-study. Cad Saude Publica. 2021;37(2):e0052720.

3. Dutra ER, Chisini LA, Cademartori MG, Oliveira LJC, Demarco FF, Correa MB. Accuracy of partial protocol to assess prevalence and factors associated with dental caries in schoolchildren between 8-12 years of age. Cad Saude Publica. 2018;34(4):e00077217.

4. Chisini LA, Cademartori MG, Francia A, Mederos M, Grazioli G, Conde MCM, et al. Is the use of Cannabis associated with periodontitis? A systematic review and meta-analysis. J Periodontal Res. 2019;54(4):311-7.

5. Borges GA, Costa RC, Nagay BE, Magno MB, Maia LC, Barao VAR, et al. Long-term outcomes of different loading protocols for implant-supported mandibular overdentures: A systematic review and meta-analysis. J Prosthet Dent. 2020.

6. Sodnom-Ish B, Eo MY, Nguyen TTH, Kim MJ, Kim SM. Clinical feasibility and benefits of a tapered, sand-blasted, and acid-etched surfaced tissue-level dental implant. Int J Implant Dent. 2020;6(1):39.

7. Howe MS, Keys W, Richards D. Long-term (10-year) dental implant survival: A systematic review and sensitivity meta-analysis. J Dent. 2019;84:9-21.

8. Becker ST, Beck-Broichsitter BE, Rossmann CM, Behrens E, Jochens A, Wiltfang J. Long-term Survival of Straumann Dental Implants with TPS Surfaces: A Retrospective Study with a Follow-up of 12 to 23 Years. Clin Implant Dent Relat Res. 2016;18(3):480-8.

9. Fischer K, Stenberg T. Prospective 10-year cohort study based on a randomized controlled trial (RCT) on implantsupported full-arch maxillary prostheses. Part 1: sandblasted and acid-etched implants and mucosal tissue. Clin Implant Dent Relat Res. 2012;14(6):808-15. 
10. Buser D, Janner SF, Wittneben JG, Bragger U, Ramseier CA, Salvi GE. 10-year survival and success rates of 511 titanium implants with a sandblasted and acid-etched surface: a retrospective study in 303 partially edentulous patients. Clin Implant Dent Relat Res. 2012;14(6):839-51.

11. Van Velzen FJ, Ofec R, Schulten EA, Ten Bruggenkate CM. 10-year survival rate and the incidence of peri-implant disease of 374 titanium dental implants with a SLA surface: a prospective cohort study in 177 fully and partially edentulous patients. Clin Oral Implants Res. 2015;26(10):1121-8.

12. Alfadda SA, Chvartszaid D, AIFarraj Aldosari A. Clinical outcomes of immediately loaded implant-supported overdentures: A long-term prospective clinical trial. J Prosthet Dent. 2019;121(6):911-5.

13. Parihar AS, Madhuri S, Devanna R, Sharma G, Singh R, Shetty K. Assessment of failure rate of dental implants in medically compromised patients. J Family Med Prim Care. 2020;9(2):883-5.

14. Bazli L, Khoramabadi $\mathrm{H}$, Chahardehi A, Arsad H, Malekpouri B. Factors influencing the failure of dental implants: $A$ systematic review. J. Compos. Compd. 2020;2:18-25.

15. Alcazar JC, Salas MM, Conde MC, Chisini LA, Demarco FF, Tarquinio SB, et al. Electrochemical Cathodic Polarization, a Simplified Method That Can Modified and Increase the Biological Activity of Titanium Surfaces: A Systematic Review. PLoS One. 2016;11(7):e0155231.

16. Yeo IL. Modifications of Dental Implant Surfaces at the Micro- and Nano-Level for Enhanced Osseointegration. Materials (Basel). 2019;13(1).

17. Abraham CM. A brief historical perspective on dental implants, their surface coatings and treatments. Open Dent J. 2014;8:50-5.

18. Liu Y, Rath B, Tingart M, Eschweiler J. Role of implants surface modification in osseointegration: A systematic review. J Biomed Mater Res A. 2020;108(3):470-84.

19. Feller L, Chandran R, Khammissa RA, Meyerov R, Jadwat $Y$, Bouckaert M, et al. Osseointegration: biological events in relation to characteristics of the implant surface. SADJ. 2014;69(3):112, 4-7.

20. Van Oirschot BA, Meijer GJ, Bronkhorst EM, Narhi T, Jansen JA, van den Beucken JJ. Comparison of different surface modifications for titanium implants installed into the goat iliac crest. Clin Oral Implants Res. 2016;27(2):e5767.

21. Yang $\mathrm{Y}$, Kim $\mathrm{KH}$, Ong JL. A review on calcium phosphate coatings produced using a sputtering process--an alternative to plasma spraying. Biomaterials. 2005;26(3):327-37.

22. Hung K, Lo S, Shish C, Yang Y, Feng H, Lin Y. Titanium surface modified by hydroxyapatite coating for dental implants. Surface and Coatings Technology. 2013;231:337-45.

23. Kim HW, Knowles JC, Salih V, Kim HE. Hydroxyapatite and fluor-hydroxyapatite layered film on titanium processed by a sol-gel route for hard-tissue implants. J Biomed Mater Res B Appl Biomater. 2004;71(1):66-76.

24. He G, Guo B, Wang H, Liang C, Ye L, Lin Y, et al. Surface characterization and osteoblast response to a functionally graded hydroxyapatite/fluoro-hydroxyapatite/titanium oxide coating on titanium surface by sol-gel method. Cell Prolif. 2014;47(3):258-66.

25. Milella E, Cosentino F, Licciulli A, Massaro C. Preparation and characterisation of titania/hydroxyapatite composite coatings obtained by sol-gel process. Biomaterials. 2001;22(11):1425-31.

26. Aksakal B, Hanyaloglu C. Bioceramic dip-coating on Ti-6Al-4V and 316L SS implant materials. J Mater Sci Mater Med. 2008;19(5):2097-104.

27. Varma HK, Babu SS. Synthesis of calcium phosphate bioceramics by citrate gel pyrolysis method. Ceram. Int. 2005;31(1):109-14.

28. De Carvalho RV, Chisini LA, Ferrua CP, Guiraldo RD, Gonini-Junior A, Moura SK, et al. The influence of concentration of HEMA on degree of conversion and cytotoxicity of a dental bonding resin. Minerva Stomatol. 2016;65(2):65-71.

29. Chisini LA, Conde MC, Alcazar JC, Silva AF, Nor JE, Tarquinio SB, et al. Immunohistochemical Expression of TGFbeta1 and Osteonectin in engineered and $\mathrm{Ca}(\mathrm{OH}) 2$-repaired human pulp tissues. Braz Oral Res. 2016;30(1):e93.

30. Naddeo P, Laino L, La Noce M, Piattelli A, De Rosa A, lezzi G, et al. Surface biocompatibility of differently textured titanium implants with mesenchymal stem cells. Dent Mater. 2015;31(3):235-43.

31. Olivares-Navarrete R, Gittens RA, Schneider JM, Hyzy SL, Haithcock DA, Ullrich PF, et al. Osteoblasts exhibit a more differentiated phenotype and increased bone morphogenetic protein production on titanium alloy substrates than on poly-ether-ether-ketone. Spine J. 2012;12(3):265-72.

32. Damiati L, Eales MG, Nobbs AH, Su B, Tsimbouri PM, Salmeron-Sanchez M, et al. Impact of surface topography and coating on osteogenesis and bacterial attachment on titanium implants. $J$ Tissue Eng. 2018;9:2041731418790694.

33. Jung UW, Hwang JW, Choi DY, Hu KS, Kwon MK, Choi SH, et al. Surface characteristics of a novel hydroxyapatitecoated dental implant. J Periodontal Implant Sci. 2012;42(2):59-63. 
34. Harunb WSW, Asria RIM, Aliasc J, Zulkiflid FH, Kadirgamab K, Ghanib SAC, et al. A comprehensive review of hydroxyapatite-based coatings adhesion on metallic biomaterials. Ceram. Int. 2017.

35. Chisini LA, Conde MCM, Grazioli G, Martin ASS, Carvalho RV, Nor JE, et al. Venous Blood Derivatives as FBSSubstitutes for Mesenchymal Stem Cells: A Systematic Scoping Review. Braz Dent J. 2017;28(6):657-68.

36. Chisini LA, Conde MCM, Grazioli G, Martin ASS, Carvalho RV, Sartori LRM, et al. Bone, Periodontal and Dental Pulp Regeneration in Dentistry: A Systematic Scoping Review. Braz Dent J. 2019;30(2):77-95.

37. Li X, Li Y, Liao Y, Li J, Zhang L, Hu J. The effect of magnesium-incorporated hydroxyapatite coating on titanium implant fixation in ovariectomized rats. Int J Oral Maxillofac Implants. 2014;29(1):196-202.

38. Zhang JX, Guana RF, Zhanga XP. Synthesis and characterization of sol-gel hydroxyapatite coatings deposited on porous NiTi alloys. J. Alloys Compd. 2011;509(13):4439-648.

39. Zhang S, Xianting Z, Yongsheng W, Kui C, Wenjian W. Adhesion strength of sol-gel derived fluoridated hydroxyapatite coatings. Surf Coat Technol 200. 2006:Surf. Coat. Technol. 200.

40. Combes C, Rey C. Amorphous calcium phosphates: synthesis, properties and uses in biomaterials. Acta Biomater. 2010;6(9):3362-78.

41. Costa DO, Dixon SJ, Rizkalla AS. One-and three-dimensional growth of hydroxyapatite nanowires during sol-gelhydrothermal synthesis. ACS Appl Mater Interfaces 2012;4:1490-9.

42. Conde MC, Chisini LA, Grazioli G, Francia A, Carvalho RV, Alcazar JC, et al. Does Cryopreservation Affect the Biological Properties of Stem Cells from Dental Tissues? A Systematic Review. Braz Dent J. 2016;27(6):633-40.

43. Brie IC, Soritau O, Dirzu N, Berce C, Vulpoi A, Popa C, et al. Comparative in vitro study regarding the biocompatibility of titanium-base composites infiltrated with hydroxyapatite or silicatitanate. J Biol Eng. 2014;8:14.

44. Yi D, Wu C, Ma B, Ji H, Zheng X, Chang J. Bioactive bredigite coating with improved bonding strength, rapid apatite mineralization and excellent cytocompatibility. J Biomater Appl. 2014;28(9):1343-53.

45. Zykova A, Safonov V, Yanovska A, Sukhodub L, Rogovskaya R, Smolik J, et al. Formation of Solution-derived Hydroxyapatite Coatings on Titanium Alloy in the Presence of Magnetron-sputtered Alumina Bond Coats. Open Biomed Eng J. 2015;9:75-82.

46. Alcázar JCB, Lemos RMJ, Conde MCM, Chisini LA, Salas MMS, Noremberg BS, et al. Preparation, characterization, and biocompatibility of different metal oxide/PEG-based hybrid coating synthesized by sol-gel dip coating method for surface modification of titanium. Progress in Organic Coatings. 2019;130:206-2013.

47. Balamurugan A, Rebelo A, Kannan S, Ferreira JM, Michel J, Balossier G, et al. Characterization and in vivo evaluation of sol-gel derived hydroxyapatite coatings on Ti6Al4V substrates. J Biomed Mater Res B Appl Biomater. 2007;81(2):441-7.

48. Queiroz TP, de Molon RS, Souza FA, Margonar R, Thomazini AH, Guastaldi AC, et al. In vivo evaluation of $\mathrm{cp} \mathrm{Ti}$ implants with modified surfaces by laser beam with and without hydroxyapatite chemical deposition and without and with thermal treatment: topographic characterization and histomorphometric analysis in rabbits. Clin Oral Investig. 2017;21(2):685-99.

49. Yazdani J, Ahmadian E, Sharifi S, Shahi S, Maleki Dizaj S. A short view on nanohydroxyapatite as coating of dental implants. Biomed Pharmacother. 2018;105:553-7.

2021 by the authors. Submitted for possible open access publication under the terms and conditions of the Creative Commons Attribution (CC BY NC) license (https://creativecommons.org/licenses/by-nc/4.0/). 